\title{
Investigating In-service Elementary School Teachers' Satisfaction with Participating in MOOC for Teaching Biological Concepts
}

\author{
Eirini Tzovla ${ }^{1 *}$, Katerina Kedraka ${ }^{1}$, Christos Kaltsidis ${ }^{1}$ \\ ${ }^{1}$ Department of Molecular Biology \& Genetics, Democritus University of Thrace, Laboratory of Teaching and Professional \\ Development of Bioscientists, GREECE
}

Received 11 December 2020 - Accepted 21 January 2021

\begin{abstract}
This paper reports on a study exploring the in-service elementary school teachers satisfaction as far as the design and implementation of a Massive Open Online Course (MOOC), which took place during the second wave of pandemic COVID-19 and prepared in-service elementary school teachers how to teach biological concepts in Primary School with the utilization of digital educational content and Open Educational Recourses (OER). A total of 251 teachers enrolled in this MOOC of whom 142 completed the course and were asked to fill-in a questionnaire. The findings indicated that the majority of the participants were satisfied both with the specific learning experience and the participation in a learning community in which interaction, support and active participation were developed. Recommendations are made for future research.
\end{abstract}

Keywords: biological concepts, digital educational content, in-service elementary school teachers, MOOC, satisfaction

\section{INTRODUCTION}

In the age of the knowledge, given the rapid changes in the field of education, the role of the teacher is constantly being redefined, as the initial knowledge and skills are no longer sufficient for the professional life. A new type of teacher is created, the lifelong learning teacher (Hammerness, Darling-Hammond, \& Bransford, 2005), who constantly looks for professional development programs, in order to enrich and improve one's personal portfolio. These programs are now a fundamental element of quality of education and are related to the professional identity of the teacher, its adaptation to the new data of education and its selfefficacy.

Avalos (2011) claims that professional development is a complex process, which includes the mental and emotional involvement of teachers at the personal level as well as at the level of cooperation. Van AalderenSmeets, and van der Molen (2015) suggest that professional development should focus on improving teacher skills to adapt their teaching to the needs of students and Kedraka (2008) states that professional development takes place during the professional life of the teacher and includes four (4) elements a) the personal development, b) the in service achievements, c) the didactic competence and d) the scientific training. The key components of professional development are constructive dialogue and the interaction between peers and between instructor and teachers (Herbert \& Rainford, 2014; Prestridge, 2013) and its aim is to be with teachers and not for teachers (Laurillard, 2016). In accordance with the aforementioned, Lumpe, Czerniak, Haney, and Beltyukova (2012) report that intensive longterm professional development programs combined with ongoing support/mentoring, increase teachers' self-efficacy and bring about better learning outcomes in the classroom.

\section{LITERATURE REVIEW}

\section{Characteristics of Teachers' Professional Development \\ Supovitz and Turner (2000), summarizing the views of many researchers, report as effective features of professional development the familiarity of the participants with models of research forms of teaching, the involvement of participants in specific activities, the utilization of experiences, the focus on content}




\section{Contribution to the literature}

- This paper presents the in-service elementary school teachers' satisfaction from a MOOC, which focus on the teaching of biological concepts in Primary School with the utilization of digital educational content and OER.

- This article contributes to the field of research on MOOCS, as the number of surveys that have investigated teachers' satisfaction with their participation in them is small, and limited MOOCS have been addressed to in-service elementary school teachers. Quantitative and qualitative methods were employed to measure the teachers' satisfaction.

- Results show that the majority of the participants were satisfied both with the design and implementation of the MOOC and from their participation in a learning community.

knowledge issues, the connection with teachers' work and learning outcomes and the linking of transformational strategies, proposed by professional development programs, with other aspects of change in school.

Recently, Darling-Hammond, Hyler, and Gardner (2017) defined the following as characteristics of effective professional development:

- focus on the content, which is linked to the curriculum and supports teachers in the educational practice,

- focus on active learning, where the teacher acts as a learner in the design and implementation of educational activities, which they are then asked to design for their students,

- support for collaborative peer learning, which strengthens the creation of communities that can change the culture of the teacher and then the culture of the school,

- contact with good practices, such as lesson plans, student activities, peer teaching observation,

- expert support and sharing of experience between those involved in the program,

- feedback and reflection between instructor and learner,

- reasonable duration, so that participants can apply and reflect on what they learn in the program.

Similarly, Blank, de las Alas and Smith (2008) after having explored twenty-five (25) professional development programs, concluded that these are effective when they consistently support participants and focus on the curriculum and the collaboration of the participants. In addition, Darling-Hammond and Richardson (2009) conclude that the successful professional development programs are collaborative and sustainable - even after their expiration - and they focus on content while enabling multiple applications in the classroom.

\section{Teachers' Professional Development and MOOC}

E-learning education has flourished in recent years in many countries and the evolution of digital technologies has given another potential to professional development programs. Digital and scientific literacy in education is a necessity -today more than ever, as demonstrated in the time of the pandemic COVID-19 (Tzovla \& Kedraka, 2020a), and also a priority of the European Commission (2020), which promotes a series of initiatives and reference frameworks in this direction. Research (Castaño-Muñoz, Kalz, Kreijns, \& Punie, 2018) shows that teachers prefer professional development's training programs involving digital technologies and having the element of optionality, because such programs are flexible and allow the autonomy of the participants. At the same time, other researchers (Fisher, Schumaker, Culbertson, \& Deshler, 2010; Fishman et al., 2013; Powell, Diamond, Burchinal, \& Koehler, 2010) state that there are no differences regarding the learning outcomes and the teaching practices that teachers adopt after their training, in relation to whether the programs they have attended are face-to-face or distant.

The use of digital technologies to provide such programs to teachers offer a number of positive elements, such as the abolition of spatio-temporal barriers, interaction with experts and peers, the involvement of a large number of participants, the possibility of multiple ways of communication (e-mail, forum) and - perhaps the most important - the opportunity given to teachers to escape from their isolated school environments (Carpenter \& Krutka, 2014) and get in touch with other educators, networks, new ideas and resources (Prestridge, 2016; Visser, Evering, \& Barrett, 2014)

In the last few years, professional development programs are offered by means of/through online platforms to a large number of participants in an asynchronous way, known as MOOCs (Massive Open Online Course). According to Bates (2019) what makes MOOCs unique are exactly the four features that make up the acronym and which provide every possible facility to those who wish to attend. MOOCs are online distance learning programs that offer massiveness, 
networking, peer learning, openness, reusability of content, specific duration, targets and educational material (European Commission, 2014). Recently MOOCs addressed teachers (online Teacher Professional Development - oTPD) giving a new dynamic to the field. Research (Kennedy \& Laurillard, 2019; Koukis \& Jimoyiannis, 2017, 2019) has shown that teachers are satisfied with the design and the implementation of TPD - MOOCs and Yoo (2016) argues that the involvement of teachers in online experiences of professional development programs improves their self-efficacy. According to Cho and Rathbun (2013) the asynchronous discussions that take place in MOOCs improve the active participation and allow the creation of self-controlled and self-directed learning environments and Rahimi, Henze, Hermans, and Barendsen (2018) state that MOOCs can link educational content to the curriculum. In this context Donitsa-Schmidt and Topaz (2018) note the general satisfaction of the participants from such a learning experience and their intention to participate in other MOOCs in the future. Borko (2004) and Guskey and Yoon (2009) agree that learning for teachers is a process of participation, practice and collaboration on teaching methods and MOOCs contribute in this direction through a flexible, collaborative and constructive process (Håklev \& Slotta, 2017; Kennedy \& Laurillard, 2019). The benefits of participation in this type of professional development programs are its usually free offer, the access they provide to OER, the creation of learning communities and the issuance of a certificate, which sometimes validates the acquisition of qualifications by the participants.

Given the acceptance and popularity of MOOCs in teacher professional development, we designed and implemented one such course, addressed to Greek inservice elementary teachers during the period of the second wave of the COVID-19 in Greece and concerned the teaching of biological concepts in Primary School and the use of digital educational content and OER in their teaching.

\section{Research Objectives}

The COVID-19 pandemic has brought to the foreground a number of issues related to teacher education and readiness to support the emergency remote teaching model. Issues such as digital skills of teachers and students, the utilization of digital educational content and OER in teaching, teachers' cognitive readiness to teach biological concepts emerged compellingly (Tzovla \& Kedraka, 2020b).

A review of the literature revealed that no professional development programs have been implemented in the form of MOOCs which aimed at inservice elementary teachers and were related to the teaching of biological concepts in Primary School and the use of digital educational content and OER. For this purpose, it was considered useful to design and implement a MOOC for teachers focusing on the above topics. The purpose of this research is to investigate the satisfaction of Greek in-service elementary school teachers from their participation in a MOOC that concerns the teaching of biological concepts in Primary School with the use of digital educational content and OER.

Therefore, the following research questions were addressed:

- Are the in-service elementary school teachers satisfied with the design of the TPD-MOOC which concerns the teaching of biological concepts in the Primary School and the utilization of digital educational content and OER?

- Are the in-service elementary school teachers satisfied with the implementation of the TPDMOOC which concerns the teaching of biological concepts in the Primary School and the utilization of digital educational content and OER?

\section{DESIGN FRAMEWORK OF THE TPD- MOOC}

The program took into account EU priorities (European Commission, 2020) and the needs of the specific target group. Consequently, it was designed in the philosophy of TPD-MOOCs, as this model of professional development has been recently applied to teachers with encouraging results both in terms of teachers' self-efficacy in the learning process and in terms of their completion rates (Koukis \& Jimoyiannis 2017; Laurillard, 2016; Ngeze \& Sridhar, 2019).

Specifically, this program was structured based on the principles of distance education and adult education and focused on activities compatible with the curriculum, the collaborative learning, the self-regulated learning and the active participation of learners. It included digital educational content and OER for the teaching of biological concepts in Primary School, acquaintance with innovative teaching practices, skills improvement related to the utilization of multiple resources and the design, implementation and evaluation of a lesson plan, which concerns the teaching of biological concepts in Primary School.

The program lasted five (5) weeks, was structured in five (5) sections with a clear schedule, each of which included educational material, additional support material from multiple sources (videos, OER, Open Educational Practices), design and implementation of activities for students in the classroom, suggestions for pedagogical approaches and support in technical issues whenever they arose. In addition, the program was designed taking into account modern design trends in elearning (Conole, 2014) and promoted: a) open learning, b) learning with others (social learning), highlighted through participation, the interaction, mutual support, 
Table 1. Structure and content of the program

Week Course topics and learning activities

$1^{\text {st }} \quad$ 1st Thematic Unit: Biology in Primary Education and the Curriculum

Familiarization with the MOOC platform.

Study of educational material. Participation in the forum of $1^{\text {st }}$ week. 1st Activity.

2nd 2nd Thematic Unit: Pedagogical utilization of Digital Educational Content and Open Educational Resources

Study of educational material. Participation in the forum of 2nd week. 2nd Activity.

$3^{\text {rd }} \quad 3 r d$ Thematic Unit: Design of a teaching proposal with the utilization of Digital Educational Content and Open

Educational Resources

Study of educational material. Participation in the forum of 3rd week. 3rdActivity.

$4^{\text {th }} \quad$ 4th Thematic Unit: Implementation and evaluation of the teaching proposals

Study of educational material. Participation in the forum of 4th week. 4th Activity.

$5^{\text {th }} \quad$ 5th Thematic Unit: Evaluation of the program - Reflection - Conclusions

Participation in the forum of 5 th week. Self-assessment of the participants in the educational material of the course. Quantitative and qualitative evaluation of the course.

sharing and creation of new knowledge and c) the selfregulation of the participants.

More specifically, the educational intervention focuses on the correlations between:

- Teacher and content

- Teacher and educator

- Teacher and teacher

- Teacher and digital technologies (Anderson, 2004).

The in-service elementary school teachers through the forum of each unit exchanged ideas and interacted in an asynchronous way. This possibility allowed for reflection on the educational material, reflection on the proposed activities and, ultimately, the widening of knowledge. They were asked to choose digital educational content and OER for biological concepts, to design and implement activities in their classroom, to contribute with their ideas to the activities of other teachers and to take into account in their own implementation the proposals of peers. The process was supported by the basic design principle of cMOOCs that learning is considered both an individual and collaborative process and aimed at social and cognitive interaction, and utilizing the colleague as a "critical friend" with the ultimate goal being the creation of a learning community.

In order for this specific teacher professional development program to succeed, we utilized data from various professional development models TPD MOOCs. Specifically, from Guskey's professional development model (2002) we exploited the element of change in teachers' teaching practices which can bring about changes in learning outcomes and finally changes in teachers' attitudes and beliefs. From the conceptual context of Desimone (2009) we exploited a) the focus on content which can contribute to the improvement of knowledge, skills and practices, b) active learning in terms of interactive feedback and discussion, c) the coherence, which concerns the connection of the content of the program with the professional needs of the teachers and d) collective participation, which is more favored through the cooperation and interaction of teachers of the same specialty and those who teach the same subjects. Finally, from the model of Guskey according Prestridge (2016) we used the role of educator/facilitator as a shaper of a community of trained teachers.

The program aimed at creating an active, professionally developed learning community which promotes the active participation of teachers (Baran \& Alzoubi, 2020) and turns them into creative activity designers so that - upon completion of the program they are able to link new pedagogical practices with digital educational content and OER and improve teachers' self-efficacy in teaching biological concepts. The program was titled "Teaching biological concepts in Primary Education using Digital Educational Content and Open Educational Resources" and was offered by the Laboratory "Teaching and Professional Development of Bioscientists" of the Department of Molecular Biology and Genetics of the Democritus University of Thrace. Table 1 shows the structure and content of all thematic units of the program.

This effort was particularly significant as it took place at a time when the COVID-19 pandemic had made digital skills, the utilization of digital educational content and the teaching of biological concepts a top priority. The project was implemented through nonconsolidated practices, supporting processes for the development of original actions and their escalation aimed at the interaction and sharing of ideas and material by cultivating a culture of collaboration.

The distance learning program was hosted on the Open e-Class 3.0 e-learning platform. This platform was chosen because it is easy and simple to use. Truly, it was used by a lot of teachers in Greece during the first wave of the COVID-19 pandemic, when schools were closed and teachers offered emergency remote teaching. As a result, many of the participants were already familiar with it, which supported the implementation of the program. 


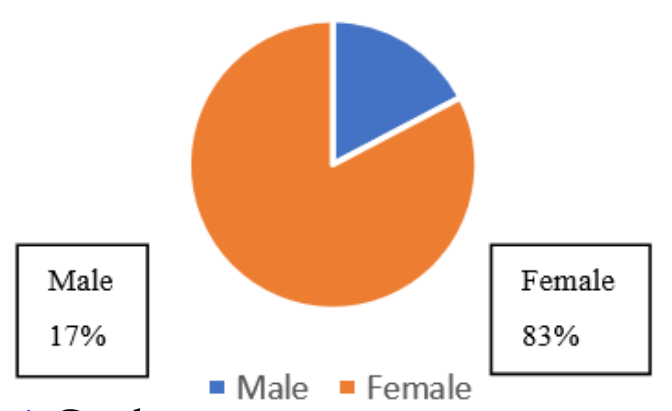

Figure 1. Gender

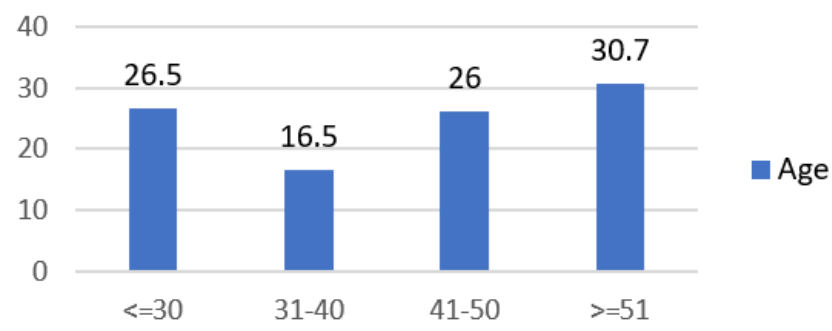

Figure 2. Age

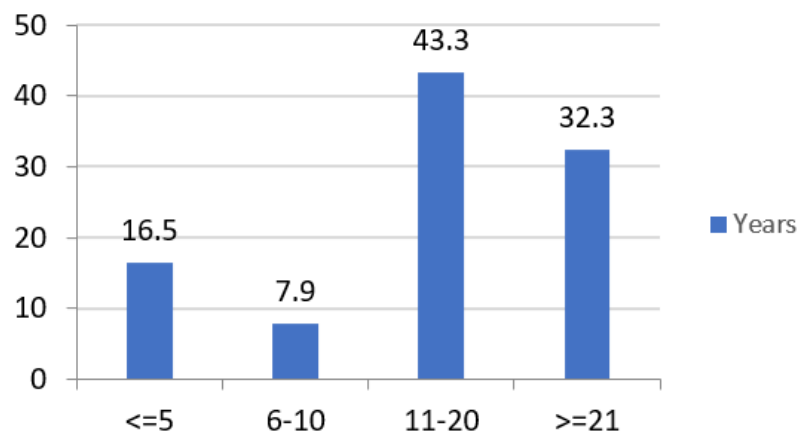

Figure 3. Teaching experience (years)

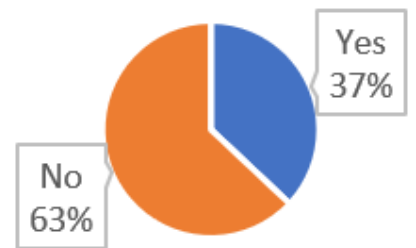

$$
\text { - Yes }=\text { No }
$$

Figure 4. Postgraduate studies

\section{METHOD}

\section{Data Collection: Procedure, Sample and Instrument}

The participants for this research were volunteers and were selected by a convenient sampling method. They are in-service teachers in elementary schools in Atttica. The data collection process started on November 1, 2020 and lasted until November 8, 2020. The instrument's final version created with Google Forms was sent to mailing lists available to the first of the coauthors who is also a teacher in Greek Primary education. 251 in-service elementary school teachers were enrolled in MOOC, 142 elementary school teachers completed it and 127 of them filled the questionnaire.
Figures 1-4 show the demographic characteristics of the participants.

During the last week of the program, participants completed an online questionnaire about their satisfaction with MOOC. The questionnaire consisted of 15 closed-ended statements rated on a 5-point Likert scale $(1=$ Not at all, $5=$ very much) regarding their satisfaction a) with the design of the MOOC and b) with the implementation of the MOOC, 5 open-ended questions about the points of the program that created the greatest satisfaction for the participants, confusion and interest and, finally, possible suggestions for improving such actions. The creation of the questionnaire was based on the available literature on the design and implementation of MOOCs, the research experience of the team of the Laboratory of Teaching and Professional Development of Bio scientists in teachers' professional development issues and the Brookfield evaluation scale.

\section{RESULTS}

\section{Data Analysis Strategy}

The data were analysed using SPSS software (SPSS 25.0). The first section describes the findings of the Exploratory Factor Analysis (EFA) and the factorability of the scale items, the second section includes the results of the descriptive statistics concerning the final 15 items in the scale and the third presents a brief summary of the findings regarding the qualitative analysis of the open questions.

\section{Factorial Structure}

\section{Exploratory factor analysis}

Principal Component Analysis (PCA) was used to identify and compute composite loadings for the factors underlying (SPSS 25.0). We examined the factorability of the 15 scale items. First of all, five iterative solutions using Varimax rotations were used to examine the factor loading matrix. It was observed that 1 out of 15 items in the initial scale had to be excluded, because they did not meet the cross-loading criterion, which was that the difference between loadings on different factors for any item should be 0.2 or above. In addition, the KaiserMeyer-Olkin measure of sampling adequacy was 0.882 , above the commonly accepted value of 0.5 (Kaiser, 1974). Table 2 presents the final PCA stage of the remaining 14 items provided the factor loading matrix.

All the variables in this analysis had strong primary loadings (between 0.53 and 0.87 ), thus confirming that each item within the three factors shared common variance with others. Given the overall indicators shown in Table 2, factor analysis was deemed to be suitable with all 14 items in the scale. 
Table 2. Factor loadings based on Principal Components Analysis (N=127)

\begin{tabular}{lccc}
\hline \multirow{2}{*}{ Item } & \multicolumn{3}{c}{ Factor Component } \\
\cline { 2 - 4 } & F1 & F2 & F3 \\
\hline 7 & 0.841 & & \\
10 & 0.790 & & \\
8 & 0.765 & & \\
9 & 0.740 & & \\
3 & 0.565 & & \\
4 & & 0.871 & \\
1 & & 0.818 & \\
2 & & 0.766 & \\
13 & & 0.657 & \\
5 & & 0.571 & \\
6 & & 0.537 & \\
14 & & 0.530 & \\
12 & & & 0.845 \\
11 & & & 0.658 \\
\hline
\end{tabular}

Factor 1 was constructed by five items, was labelled "Educational material and course organization" and represented the course's structure and the educational material. Factor 2 was labelled "Course design and implementation", was constructed by seven items and represented the subject, the design and the interaction. Finally, Factor 3 represented the reason of the participation to the course and was labelled "Incentives for participation in the Course".

Factor extraction was based on the $\mathrm{K} 1$ rule (eigenvalue $>1$ ). The three factors revealed in our analysis and the corresponding eigenvalues are shown in the Scree plot of Figure 5.

\section{Descriptive statistics}

Table 3 presents the main findings of the descriptive statistics of teachers' views regarding their satisfaction of MOOC. The Cronbach's alpha was $\alpha=0.790$ and proves that the internal consistency of the questionnaire is very good, thus indicating a good level of internal reliability (DeVellis, 2003). The majority of participants were satisfied with their participation in the program, as shown by the Mean. The most important parameters of

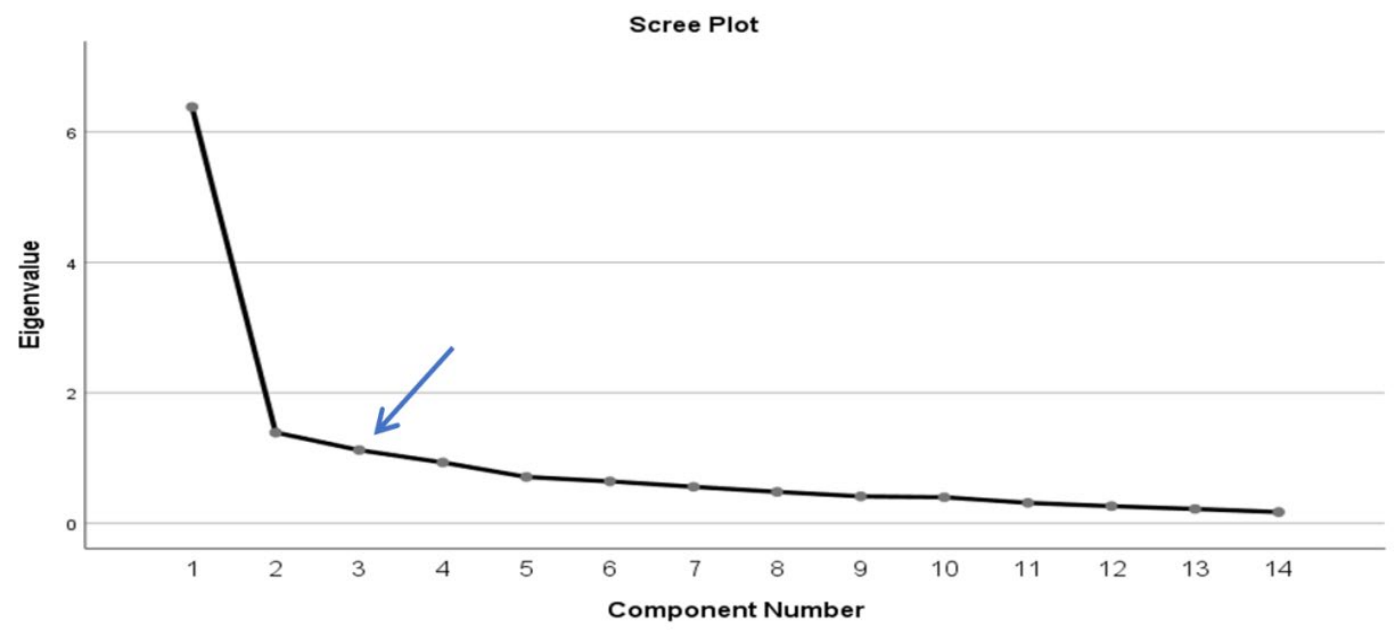

Figure 5. Scree Plot representing the three factors of the scale

Table 3. Statements of satisfaction from the distance program $(\mathrm{N}=127)$

\begin{tabular}{|c|c|c|}
\hline Statement & Mean & SD \\
\hline 1. The subject of the course was interesting to me. & 4.63 & 0.544 \\
\hline 2. The subject of the course was useful to me. & 4.64 & 0.560 \\
\hline 3. The course had achievable goals for me. & 4.55 & 0.609 \\
\hline 4. My initial objectives from the course were satisfied. & 4.30 & 0.785 \\
\hline 5. The course was flexible and oriented to my educational needs. & 4.66 & 0.536 \\
\hline $\begin{array}{l}\text { 6. The design of the course focused on the pedagogical framework of digital educational content and the } \\
\text { OER and the implementation of student-centered teaching approaches. }\end{array}$ & 4.61 & 0.567 \\
\hline 7. The pace of the course was clear to me. & 4.67 & 0.514 \\
\hline 8. The educational material was sufficient for the tasks assigned. & 4.65 & 0.575 \\
\hline 9. The structure-organization of the course in thematic units per week was appropriate-functional. & 4.68 & 0.566 \\
\hline 10. The time structure of the course was appropriate for the tasks assigned. & 4.50 & 0.718 \\
\hline 11. The free participation played an important role for me to attend this course. & 4.48 & 0.847 \\
\hline 12. The Certificate of Attendance played an important role in my decision to enroll to this Course. & 3.57 & 1.094 \\
\hline $\begin{array}{l}\text { 13. The design of the course aimed the interaction of the teachers with each other and their active } \\
\text { involvement. }\end{array}$ & 4.45 & 0.672 \\
\hline 14. The help from the instructor was sufficient for the implementation of the assigned tasks. & 4.72 & 0.552 \\
\hline 15. I encountered difficulties while attending the course. & 1.76 & 1.093 \\
\hline
\end{tabular}


Table 4. Satisfaction regarding participation in the MOOC

\begin{tabular}{|c|c|}
\hline Item & Indicative quotes \\
\hline $\begin{array}{l}\text { At what point in MOOC did } \\
\text { you feel most satisfied? }\end{array}$ & $\begin{array}{l}\text { T7:"I was very satisfied throughout the program. But the most important moment was when I saw } \\
\text { that my posts were read and evaluated positively by my colleagues and the instructor. " } \\
\text { T31:"When I completed the teaching plan for the biological concept I had chosen." }\end{array}$ \\
\hline $\begin{array}{l}\text { Which phase in MOOC } \\
\text { caused you the most } \\
\text { confusion? }\end{array}$ & $\begin{array}{l}\text { T11: "I was not confused. All the steps were understandable." } \\
\text { T75: "I did not feel confused at any stage, I just think that the whole course was very well } \\
\text { structured from beginning to end." }\end{array}$ \\
\hline $\begin{array}{l}\text { What aroused your greatest } \\
\text { interest in MOOC? }\end{array}$ & $\begin{array}{l}\text { T111: "The subject of the program, first of all, was very interesting .... For the first time there was } \\
\text { a MOOC for teaching biological concepts .... The realization of the existence of the concept of } \\
\text { Biology in many cognitive objects. " } \\
\text { T43: "The incredible pool of didactic proposals gathered by colleagues during the MOOC... } \\
\text { Didactic proposals for all grades of Primary School and for all the biological concepts, which we are } \\
\text { called to teach according to Curriculum." }\end{array}$ \\
\hline $\begin{array}{l}\text { What was the most } \\
\text { important thing you learned } \\
\text { during the Program? }\end{array}$ & $\begin{array}{l}\text { T89: "How important it is to be a member of an active learning community and to draw support } \\
\text { from it - through communication with teachers who face similar anxieties as you." } \\
\text { T123:"The ability to approach biological concepts with many and easy ways... and how to include } \\
\text { digital educational content and OER in my teaching." }\end{array}$ \\
\hline $\begin{array}{l}\text { Do you have any suggestions } \\
\text { for improving such actions? }\end{array}$ & $\begin{array}{l}\text { T12: "I look forward to participating in future activities of this university for the teaching of } \\
\text { Biology, as this action was special." } \\
\text { T45 Course could be extended to more hours so that we have even more knowledge on the subject } \\
\text { but also because we had such a nice atmosphere and had such a good time... in a course that was } \\
\text { offered for free." }\end{array}$ \\
\hline
\end{tabular}

satisfaction were: a) the help from the instructor for the implementation of the assigned tasks, b) the appropriate and functional structure and organization of the course, c) the clear and organized pace of the course d) the flexibility of the course and how adaptive it was to their educational needs and e) the adequacy of the educational material. The low Mean $(<4.0)$ in the statements regarding the difficulties during the implementation of the program and the role of a certificate of attendance confirms that the participants did not face any particular difficulties and that the certificate was not among the significant incentives for their enrolment to that program.

\section{Findings of the Qualitative Data Analysis}

The questionnaire also included 5 open-ended questions, aimed at the overall assessment of the MOOC. Specifically, teachers were asked to submit their views on their satisfaction and interest in the program and to suggest changes and/or improvements for future actions.

Through the thematic analysis of the content of the answers, individual thematic axes in each question emerged. Regarding the moment of the course when the participants felt the most satisfaction, the majority mentioned the moment when they completed the design of their teaching proposal and the moment when they received positive feedback from the instructor and their peers. Regarding the phase that caused them the most confusion, the vast majority noted that there was no such stage, stating that this is attributed to the systematic organization and support of the program. As for the part of the course with the greatest interest the teachers named the topic of the course and the teaching proposals with which they came in contact. In addition, they stated that they learned to interact as members of a learning community and that they learned to use digital educational content and OER in teaching biological concepts through innovative methods and practices. Finally, regarding the improvement proposals, they suggested a longer duration of such kinds of courses in the future and the repetition of courses with related topics due to the need for training in Biology and because of the pleasant atmosphere that had been created during the MOOC. Table 4 lists the open-ended questions of the questionnaire and indicative quotes ( $\mathrm{T}$ $=$ Teacher).

\section{DISCUSSION AND CONCLUSIONS}

Quantitative and qualitative data of the research showed that Greek elementary school teachers are satisfied with their participation in an MOOC, which concerns the teaching of biological concepts in Primary School. This is confirmed by the significant percentage of teachers who completed the course, although the literature review showed that the percentages that complete such programs are usually low (Eriksson, Adawi, \& Stohr 2017; Jordan, 2015; Shah, Banerjee, Murthy, \& Iyer, 2018; Shangying \& Jing, 2017). Our research showed the general satisfaction of the participants from the specific learning experience, a finding that agrees with the results of Dalton, Grant, and Perez (2014) and Donitsa-Schmidt and Topaz (2018). The participants expressed their satisfaction with the educational material, its design and implementation, a finding that confirms Koukis and Jimoyiannis (2017, 2019). Moreover, they noted their satisfaction from the flexibility and adaptation of the course to their 
educational needs, result which agrees with the findings from Kennedy and Laurillard (2019). Likewise, the satisfaction from the constant encouragement, support and feedback with constructive comments from the instructor was demonstrated in our research as well as in the research of Prestridge and Tondeur (2015). Corresponding satisfaction was reported from the substantial interaction and active participation between peers, result which was confirmed by research of Baran and Alzoubi (2020), Cho and Rathbun (2013). Also important is the finding regarding the satisfaction that the participants received from the collaboration, within the learning community, which contributed to the effective learning of the participants, finding that confirm Håklev and Slotta (2017). Finally, they expressed their desire to participate in similar actions in the future, finding that confirms existing findings of Donitsa-Schmidt and Topaz (2018).

In addition, our research highlighted the increased interest that exists in teaching biological concepts in Primary Education, as so far, no MOOCs have been implemented which relate to the specific subject. Given the COVID-19 pandemic, the need for biological literacy through the utilization of digital technologies in Primary Education contributes to the creation of conscious and responsible students and then citizens (Tzovla \& Kedraka, 2020b). In this context, the perspective of designing and implementing such courses that combine biological concepts and digital technologies should be integrated into the educational policies since they are priorities for education. After the pandemic, education at all levels will no longer be the same. MOOCs have a number of advantages and they can significantly contribute to teachers' professional development, through their participation in teachers' learning communities (Stenman \& Pettersson, 2020) professional learning networks and school networks as well (Hilli, 2018).

From the qualitative and quantitative data of the answers of the participants in the MOOC it, also, appear that this contributed to their personal development, as it improved their self-confidence and self-efficacy in teaching biological concepts through their involvement with biological concepts and their involvement in the design and implementation of teaching proposals. In addition, the program assisted in their career development, as the issuance of a certificate by the Laboratory of Teaching and Professional Development of Bio scientists can be counted on their formal qualifications. Moreover, the contribution of the MOOC to the teaching competence of the participants was also essential, as their pedagogical development on the teaching of biological concepts improved through their contact with innovative teaching practices and methods, the utilization of digital educational content and OER and the cultivation of building skills of learning activities. Rahimi et al. (2018) report the contribution of
MOOCs precisely in this dimension. Furthermore, the participants gained new knowledge in the field of Biology, connected through activities the curriculum with the educational process and teaching practices, thus improving their scientific training.

Finally, it is important to note that the results of the present study should be interpreted in the light of some limitations. Given that the teachers were volunteers, the research held in the area of Attica and the sampling was convenience it is not safe to generalize the results. Moreover, the fact that volunteers were asked to present their views is an issue that usually leads to response biases (Lavidas \& Gialamas, 2019; Lavidas, Dalapa, Dimitriadi, \& Athanassopoulos, 2019). Another limitation is the lack of previous research regarding the specific target group and the specific cognitive object. Our future research will be directed to the comparative analysis of both qualitative and quantitative data from $\mathrm{K}-12$ teachers on the specific topic.

Author contributions: All authors have sufficiently contributed to the study, and agreed with the results and conclusions.

Funding: No funding source is reported for this study.

Declaration of interest: No conflict of interest is declared by authors.

\section{REFERENCES}

Anderson, T. (2004). Toward a theory of online learning. In T. Anderson \& F. Elloumi (Eds.), Theory and practice of online learning (pp. 33-60). Athabasca University.

Avalos, B. (2011). Teacher professional development in Teaching and Teacher Education over ten years. Teaching and Teacher Education, 27, 10-20. https:// doi.org/10.1016/j.tate.2010.08.007

Baran, E., \& Alzoubi, D. (2020). Human-centered design as a frame for transition to remote teaching during the COVID-19 pandemic. Journal of Technology and Teacher Education, 28(2), 365-372. Retrieved on 5 December 2020 from https://www.learntechlib. org/primary/p/216077

Bates, A. W. (2019). Teaching in a Digital Age (2nd Ed.). Vancouver, B.C.: Tony Bates Associates Ltd.

Blank, R. K., de las Alas, N., \& Smith, C. (2008). Does Teacher Professional Development Have Effects on Teaching and Learning? Evaluation Findings from Programs in 14 States. Washington, DC: Council of Chief State School Officers.

Borko, H. (2004). Professional development and teacher learning: Mapping the terrain. Educational Researcher, 33(8), 3-15. https://doi.org/10.3102/ 0013189X033008003

Carpenter, J. P., \& Krutka, D. G. (2014). How and why educators use Twitter: A survey of the field. Journal of Research on Technology in Education, 46(4), 414-434. https:// doi.org/10.1080/15391523.2014.925701 
Castaño-Muñoz, J., Kalz, M., Kreijns, K., \& Punie, Y. (2018). Who is taking MOOCs for teachers' professional development on the use of ICT? A crosssectional study from Spain. Technology, Pedagogy and Education, 27(5), 607-624. https:/ / doi.org/10.1080/1475939X.2018.1528997

Cho, M. H., \& Rathbun, G. (2013). Implementing teachercentred online teacher professional development (oTPD) programme in higher education: A case study. Innovations in Education and Teaching International, 50(2), 144-156. https://doi.org/ $10.1080 / 14703297.2012 .760868$

Conole, G. (2014). A new classification schema for MOOCs. The International Journal for innovation and quality in learning, 2(3), 65-77.

Dalton, E., Grant, K. \& Perez, L. (2014). SOOC: A New Model for Online Professional Learning Communities Focus: Universal Design for Learning. In T. Bastiaens (Ed.), Proceedings of World Conference on E-Learning (pp. 454-462). New Orleans, LA, USA: Association for the Advancement of Computing in Education (AACE). Retrieved on 20 January 2020 from https:// www.learntechlib.org/primary/p/149010

Darling-Hammond, L., Hyler, M. E. \& Gardner, M. (2017). Effective Teacher Professional Development. Palo Alto, CA: Learning Policy Institute.

Darling-Hammond, L., \& Richardson, N. (2009). Teacher learning: What matters? Educational Leadership, 66(5), 46-53.

DeVellis, R. F. (2003). Scale development: Theory and applications. London, UK: Sage.

Donitsa-Schmidt, S., \& Topaz, B. (2018). Massive open online courses as a knowledge base for teachers. Journal of Education for Teaching, 44(5), 608-620. https:/ / doi.org/10.1080/02607476.2018.1516350

Eriksson, T., Adawi, T., \& Stohr, C. (2017). Time is the bottleneck: a qualitative study exploring why learners drop out of MOOCs. Journal of Computing in Higher Education, 29(1), 133-146. https: / / doi.org/ $10.1007 /$ s12528-016-9127-8

European Commission (2014). Report on Web Skills Survey: Support Services to Foster Web Talent in Europe by Encouraging the use of MOOCs Focused on web Talent-First Interim Report. https://www. openeducationeuropa.eu/sites/default/files/new s/MOOCs-for-webskills-survey-report.pdf

European Commission (2020). Digital Education Action Plan 2021-2027. Resetting education and training for the digital age. Brussels.

Fisher, J. B., Schumaker, J. B., Culbertson, J., \& Deshler, D. D. (2010). Effects of a computerized professional development program on teacher and student outcomes. Journal of Teacher Education, 61(4), 301312. https:/ / doi.org/10.1177/0022487110369556
Fishman, B., Konstantopoulos, S., Kubitskey, B. W., Vath, R., Park, G., Johnson, H., \& Edelson, D. C. (2013). Comparing the impact of online and face-toface professional development in the context of curriculum implementation. Journal of Teacher Education, 64(5), 426-438. https:/ / doi.org/10.1177/ 0022487113494413

Desimone, L. M. (2009). Improving impact studies of teachers' professional development: Toward better conceptualizations and measures. Educational Researcher, 38(3), 181-199. https://doi.org/10.3102 /0013189X08331140

Field, A. (2013). Discovering statistics using IBM SPSS statistics. 5th edition. Sage. London.

Guskey, T.R. (2002). Professional development and teacher change. Teachers and Teaching: Theory and Practice, 8(3/4), 381-391. https://doi.org/10.1080/ 135406002100000512

Guskey, T. R., \& Yoon, K. S. (2009). What works in professional development? Phi delta kappan, 90(7), 495-500. https:/ / doi.org/10.1177/003172170909000709

Håklev, S., \& Slotta, J. D. (2017). A Principled Approach to the Design of Collaborative MOOC Curricula. In C. Delgado Kloos, P. Jermann, M. PérezSanagustín, D. Seaton, \& S. White (Eds.), Digital Education: Out to the World and Back to the Campus. EMOOCs 2017. Lecture Notes in Computer Science, vol. 10254. Springer, Cham.

Hammerness, K., Darling-Hammond, L., \& Bransford, J. (2005). How teachers learn and develop. In L. Darling-Hammond \& J. Bransford (Eds.), Preparing teachers for a changing world: What teachers should learn and be able to do, 358-389. San Francisco: JosseyBass.

Herbert, S., \& Rainford, M. (2014). Developing a model for continuous professional development by action research. Professional development in education, 40(2), 243-264.

https:/ / doi.org/10.1080/19415257.2013.794748

Hilli, C. (2018). Distance teaching in small rural Primary Schools: A participatory action research project. Educational Action Research, 28(1), 38-52. https://doi.org/10.1080/09650792.2018.1526695

Jordan, K. (2015). Massive open online course completion rates revisited: Assessment, length and attrition. The International Review of Research in Open and Distributed Learning 16(3), 341-358. https:/ / doi.org/10.19173/irrodl.v16i3.2112

Kaiser, H.F. (1974). An index of factorial simplicity. Psychometrika, 39(1), 31-36.

Kedraka, K. (2008). Supporting the professional development of teachers in a school unit: principles, prerequisites and suggestions. Ta Ekpaideutika, 87-88, 111-124. [in Greek] 
Kennedy, E., \& Laurillard, D. (2019). The potential of MOOCs for large-scale teacher professional development in contexts of mass displacement. London Review of Education, 17(2), 141-158. https:/ / doi.org/10.18546/LRE.17.2.04

Koukis, N., \& Jimoyiannis, A. (2017). Designing MOOCs for teacher professional development: Analysis of participants' engagement. In A. Mesquita \& P. Peres (Eds.), Proceedings of the 16th European Conference on e-Learning, ECEL 2017 (pp. 271-280). Porto: ACPI.

Koukis, N. \& Jimoyiannis, A. (2019). MOOCS for teacher professional development: exploring teachers' perceptions and achievements. Interactive Technology and Smart Education, 16(1), 74-91. https:/ / doi.org/10.1108/ITSE-10-2018-0081

Laurillard, D. (2016). The educational problem that MOOCs could solve: professional development for teachers of disadvantaged students. Research in Learning Technology, 24(1), 29369. https:/ / doi.org/10.3402/rlt.v24.29369

Lavidas, K., Dalapa, M., Dimitriadi, S., Athanassopoulos, S., (2019). Four Job Satisfaction's dimensions of secondary education teachers: An Exploratory Factor Analysis based on a Greek sample. Preschool \& Primary Education, 7(2). https:// doi.org/10.12681/ppej.20412

Lavidas, K., \& Gialamas, V. (2019). Adaption and psychometric properties of the short forms Marlowe-Crowne social desirability scale with a sample of Greek university students. European Journal of Education Studies, 6(8), 230-239. https: / / doi.org/10.5281/zenodo.3552531

Lumpe, A., Czerniak, C., Haney, J., \& Beltyukova, S. (2012). Beliefs about teaching science: The relationship between elementary teachers' participation in professional development and student achievement. International Journal of Science Education, 34(2), 153-166. https:/ / doi.org/10.1080/ 09500693.2010 .551222

Ngeze, L. V., \& Sridhar, I. (2019). Online Teacher Professional Development in ICT Integration in Tanzania: An Experience Report. In J. L. Shih, et al. (Eds.), Proceedings of the 27th International Conference on Computers in Education. Taiwan: Asia-Pacific Society for Computers in Education.

Powell, D. R., Diamond, K. E., Burchinal, M. R., \& Koehler, M. J. (2010). Effects of an early literacy professional development intervention on head start teachers and children. Journal of Educational Psychology, 102(2), 299-312. https://doi.org/ $10.1037 / \mathrm{a} 0017763$

Prestridge, S. (2013). Reflective blogging as part of ICT professional development to support pedagogical change. The Australian Journal of Teacher Education,
39(2), 70-86. https://doi.org/10.14221/ajte.2014 v39n2.4

Prestridge, S. (2016). Conceptualising self-generating online teacher professional development. Technology, Pedagogy and Education, 26(1), 85-104. https:/ / doi.org/10.1080/1475939X.2016.1167113

Prestridge, S., \& Tondeur, J. (2015). Exploring elements that support teachers' engagement in online professional development. Education Sciences, 5(3), 199-219. https:/ / doi.org/10.3390/educsci5030199

Rahimi, E., Henze, I., Hermans, F., \& Barendsen, E. (2018). Investigating the Pedagogical Content Knowledge of Teachers Attending a MOOC on Scratch Programming. In S. Pozdniakov, \& V. Dagienè (Eds.), Informatics in Schools. Fundamentals of Computer Science and Software Engineering. ISSEP 2018. Lecture Notes in Computer Science, vol. 11169 (pp. 180-193). Springer, Cham. https:/ / doi.org/10.1007/978-3-030-02750-6_14

Shah, V. G., Banerjee, G., Murthy, S., \& Iyer, S. (2018). Learner-Centric MOOC for Teachers on Effective ICT Integration: Perceptions and Experiences. 2018 IEEE Tenth International Conference on Technology for Education (T4E), 77-84. https://doi.org/10.1109/ T4E.2018.00023

Shangying, Y., \& Jing, S. (2017). Learning to Learn from MOOCs from Teachers' Perspective: Data Analysis Based on the Course "Micro-Class Design and Production". International Conference of Educational Innovation through Technology (EITT), Osaka (pp. 14). https://doi.org/10.1109/EITT.2017.9

Stenman, S., \& Pettersson, F. (2020). Remote teaching for equal and inclusive education in rural areas? An analysis of teachers' perspectives on remote teaching. The International Journal of Information and Learning Technology, 37(3), 87-98. https://doi.org/ 10.1108/IJILT-10-2019-0096

Supovitz, J. A., Mayer, D. P., \& Kahle, J. B. (2000). Promoting inquiry-based instructional practice: The longitudinal impact of professional development in the context of systemic reform. Educational Policy, 14(3), 331-356. https://doi.org/ $10.1177 / 0895904800014003001$

Tzovla, E., \& Kedraka, K. (2020a). Teaching Biology in Primary Education. International Journal of Educational Technology and Learning, 8(2), 91-97. https:/ / doi.org/https:/ / doi.org/10.20448/2003.8 2.91 .97

Tzovla, E., \& Kedraka, K. (2020b). Personal biology teaching efficacy beliefs and biology teaching outcome expectancy of in-service elementary teachers. European Journal of Education Studies, 7(10), 143-159. https:/ / doi.org/10.46827/ejes.v7i10.3286

van Aalderen-Smeets, S. I., \& van der Molen, J. H. (2015). Improving Primary teachers' attitudes toward 
science by attitude-focused professional development. Journal of research in science teaching, 52(5), 710-734. https:/ / doi.org/10.1002/tea.21218

Visser, R. D., Evering, L. C., \& Barrett, D. E. (2014). \#TwitterforTeachers: The implications of Twitter as a self-directed professional development tool for K12 teachers. Journal of Research on Technology in Education, 46(4), 396-413. https:/ / doi.org/10.1080/ 15391523.2014 .925694
Yong, A. G., \& Pearce, S. (2013). A beginner's guide to Factor Analysis: Focusing on Exploratory Factor Analysis. Tutorials in Quantitative Methods for Psychology, 9(2), 79-94. https://doi.org/10.20982/ tqmp.09.2.p079

Yoo, J. H. (2016). The effect of professional development on teacher efficacy and teachers' self-analysis of their efficacy change. Journal of Teacher Education for Sustainability, 18(1), 84-94. https:// doi.org/10.1515 /jtes-2016-0007

http://www.ejmste.com 